\title{
Role of Oxygen in Antibody-dependent Cytotoxicity Mediated by Monocytes and Neutrophils
}

\author{
Niels BorregaArd and Knud Kragballe, Department of Medicine and \\ Infectious Diseases, Department of Dermatology, Marselisborg Hospital, \\ DK-8000 Aarhus C., Denmark
}

A B S T RA C T The antibody-dependent cell-mediated cytoxicity (ADCC) by human monocytes and neutrophils was investigated by measuring the release of ${ }^{51}$ chromate from prelabeled erythrocytes coated with immunoglobulin G. ADCC was found to be positively correlated to phagocytosis of ${ }^{51} \mathrm{Cr}$-labeled erythrocytes and to the postphagocytic events of the effector cells, activation of the hexose monophosphate shunt, and degranulation.

Exclusion of oxygen from the incubation media halved the ADCC by both cell types without affecting phagocytosis or degranulation. Likewise, ADCC by cells from patients suffering from chronic granulomatous disease (CGD) was only half the intensity of ADCC by cells from normals. Inhibitors of mitochondrial respiration were without depressing effect on ADCC. Azide, which in addition to its blocking action on oxydative phosphorylation also inhibits catalase and myeloperoxidase, resulted in $a \cong 40 \%$ stimulation of ADCC by cells from normals but was without effect on ADCC by cells from CGD patients. The hydroxyl radical scavenger, mannitol, significantly depressed ADCC by cells from normals $(P<0.01)$ but was without effect on cells from CGD patients. Azide and mannitol also were without effect on ADCC by normal cells when oxygen was excluded.

In a xanthine-xanthine oxidase system, erythrocytes were effectively lysed. This lysis was inhibited by catalase, superoxide dismutase, and mannitol. When comparable concentrations of glucose oxidase were used no lysis was observed. $\mathrm{H}_{2} \mathrm{O}_{2}$ either alone or in combination with azide did not lyse erythrocytes.

It is suggested that ADCC by both monocytes and neutrophils is partly dependent on the generation of hydroxyl radicals by the effector cells.

Received for publication 4 March 1980 and in revised form 23 June 1980.

\section{INTRODUCTION}

Antibody-dependent cell-mediated cytotoxicity (ADCC) ${ }^{1}$ refers to the lysis of target cells sensitized with IgG antitarget cell antibody by effector cells. Using antibody-sensitized human erythrocytes as target cells, the process is mediated by human monocytes and neutrophils (1-3).

In concert with the cytolysis, phagocytosis of the IgG-coated target cells takes place $(4,5)$. The mechanisms producing the cytotoxic effect are unclear. Stable soluble cytotoxic mediators are not involved $(3,4)$. However, cytotoxic mediators that might require high local concentrations in regions of intimate membrane apposition cannot be excluded (6). Recent observations by Clark and Klebanoff (7) and Katz et al. (8) indirectly implicate a role of reduced oxygen radicals generated by the effector cells because ADCC was found significantly depressed in effector cells from patients suffering from chronic granulomatous disease (CGD). CGD is characterized by the lack of ability of neutrophils to form reduced oxygen radicals upon challenge despite normal phagocytosis (9). However, Fleer et al. (10) found normal ADCC in cells from CGD patients and found no evidence of oxygen radicals participating in ADCC.

The present investigation was carried out to delineate the role of oxygen radicals in ADCC. In view of the frequent infections of CGD patients, normal cells were investigated under aerobic and anaerobic conditions because the sole use of CGD patients to investigate the role of oxygen radicals might introduce a bias in the methodology. Cells from patients and

\footnotetext{
'Abbreviations used in this paper: ADCC, antibodydependent cell-mediated disease; CGD, chronic granulomatous disease; FCS, fetal calf serum; HBSS, Hanks' balanced salt solution; HMPS, hexose monophosphate shunt; IgG-latex, IgG-coated latex particles; LDH, lactate dehydrogenase; PMA, phorbol-12-myristate-13-acetate; SOD, superoxide dismutase.
} 
carriers of CGD were, however, also included. The lysing effect of a xanthine-xanthine oxidase system was investigated to further identify the oxygen radical responsible for cell lysis.

\section{METHODS}

Antimycin A, catalase (bovine liver $15,300 \mathrm{U} / \mathrm{mg}$ ), cytochrome c (horse heart type VI), glucose oxidase (type VII), Micrococcus lysodeikticus, phorbol-12-myristate-13-acetate (PMA), superoxide dismutase (SOD) (bovine blood, $2,900 \mathrm{U} / \mathrm{mg}$ ), and xanthine oxidase (grade I, from buttermilk) were obtained from Sigma Chemical Co., St. Louis, Mo. 2,4-dinitrophenol was obtained from BDH Chemicals Ltd., Poole, England Fetal calf serum (FCS) was obtained from Gibco, Glasgow, Scotland. Hyperimmune human anti-B serum was a generous gift from the Blood Bank and Blood Group Laboratory, Aarhus, Denmark. Immunoglobulin for coating latex particles was obtained from Statens Seruminstitut, Copenhagen, Denmark. Instagel was obtained from Packard Instrument Co., Inc., Downers Grove, Ill. Latex particles, diameter 0.81 $\mu \mathrm{m}$, were obtained from Difco Laboratories, Detroit, Mich Lymphoprep was obtained from Nygaard, Oslo, Norway RPMI-1640 was obtained from Gibco. $\left[1-{ }^{14} \mathrm{C}\right]$ glucose, $\left[6-{ }^{14} \mathrm{C}\right]-$ glucose, and sodium ${ }^{51}$ chromate $(1 \mathrm{mCi} / \mathrm{ml}, 2-10 \mu \mathrm{g} / \mathrm{ml})$ were obtained from The Radiochemical Centre Ltd., Amersham, England. All other chemicals were reagent grade.

Subjects. Peripheral venous blood was obtained from healthy staff members who had given informed consent. CGD patients were identified by their neutrophils having $(a)$ abolished killing of staphylococci despite normal phagocytosis, $(b)$ abolished activation of oxygen consumption and hexose monophosphate shunt upon stimulation by PMA and IgG-coated latex particles, and $(c)$ abolished superoxide liberation upon PMA stimulation. Carriers were either mothers or sisters of affected boys and had a clearly reduced but not abolished response in the above mentioned parameters.

Purification of cells. $100-200 \mathrm{ml}$ blood was withdrawn and stabilized by preservation-free heparin, $20 \mathrm{IU} / \mathrm{ml}$.

Monocytes. The heparinized blood was centrifuged over Ficoll-Isopacque (Lymphoprep) as described by Boyum (11) The mononuclear cells of the interface layer were washed twice in Hanks' balanced salt solution (HBSS) with $2.5 \%$ (vol/vol) heat-inactivated FCS, resuspended in RPMI-1640) supplemented with $25 \%$ (vol/vol) FCS, and dispended in tissue-culture flasks. After $1 \mathrm{~h}$ at $37^{\circ} \mathrm{C}$ in a humidified atmosphere containing $5 \% \quad \mathrm{CO}_{2}$, the nonadherent cells were decanted and the flasks rinsed with three changes of HBSS, $2.5 \%$ FCS at $37^{\circ} \mathrm{C}$. HBSS, $2.5 \% \mathrm{FCS}$, was then introduced to the flasks with adherent monocytes and the flasks placed in ice water for $30 \mathrm{~min}$. Detached monocytes were then decanted and the flasks rinsed three times with HBSS, $2.5 \%$ FCS. The collected monocytes were centrifuged at $150 \mathrm{~g}$ for $10 \mathrm{~min}$. Using alpha naphtyl acetate as substrate, cytocentrifuged preparations were stained to detect activity of nonspecific esterase (12). The median percentage of monocytes showing diffuse cytoplasmic activity was 91, ranging from 82 to 96 . Granulocytes up to $3 \%$ were occasionally found. The other contaminating cells were lymphocytes.

Neutrophils. After sedimentation for $30 \mathrm{~min}$ at $37^{\circ} \mathrm{C}$ in the presence of $2 \%(\mathrm{wt} / \mathrm{vol})$ dextran $\mathrm{T} 150$, the leukocyte-rich supernate of the heparin-stabilized blood was withdrawn and centrifuged over Ficoll-Isopaque as described by Boyum (11). The supernate was discarded and the pellet resuspended in $10 \mathrm{ml}$ water for $45 \mathrm{~s}$ for the hemolysis of contaminating erythrocytes. Isotonicity was then restored with hypertonic saline and the cells washed twice in HBSS. The preparation was $>97 \%$ pure as judged by morphological criteria. More than $96 \%$ of the cells excluded trypan blue.

Cytotoxicity assay: target cells. For all experiments, fresh type B Rh-negative human erythrocytes from the same donor were used. Equal volumes of washed erythrocytes, $2 \times 10^{8} / \mathrm{mI}$, and sodium ${ }^{51}$ chromate were mixed and incubated for $60 \mathrm{~min}$ at $37^{\circ} \mathrm{C}$. After this labeling procedure, the erythrocytes were washed twice.

Antibody. Human hyperimmune antiserum to type B human erythrocytes (anti-B serum) was heat-inactivated and stored after lyophilization at $-20{ }^{\circ} \mathrm{C}$. A dilution to $10 \%(\mathrm{vol} / \mathrm{vol})$ final concentration, which induced maximal target cell lysis in the ADCC system, was used. The same lot of anti-B serum was used in all experiments.

Assay procedure. The tests were set up in duplicate in round-bottomed plastic tubes. All dilutions were made in HBSS containing $10 \%$ (vol/vol) RPMI-1640, $5 \%$ (vol/vol) FCS, $100 \mathrm{IU} / \mathrm{ml}$ penicillin, $100 \mu \mathrm{g} / \mathrm{ml}$ streptomycin, and $25 \mathrm{mM}$ HEPES, pH 7.4. To 100$) \mu$ l effector cells (monocyte's or neutrophils, $1 .()-3.0 \times 10^{6}$ cells $/ \mathrm{ml}$ ) were added $1(0) \mu{ }^{51} \mathrm{Cr}$-labeled erythrocytes $\left(1.0-9.0 \times 10^{6} / \mathrm{ml}\right)$ and $100 \mu \mathrm{l}$ anti-B serum dilution. In some experiments other additions were made as indicated. This was done in a volume of $30 \mu$ l. The tubes were capped, centrifuged at $150 \mathrm{~g}$ for $1 \mathrm{~min}$, and incubated at $37^{\circ} \mathrm{C}$ in a water bath for the time indicated. Controls in which the effector cells were replaced by unlabeled erythrocytes or in which the anti-B serum was replaced by human AB serum, were included. After incubation the tubes were centrifuged at $300 \mathrm{~g}$ for $10 \mathrm{~min}$ and half of the supernate was withdrawn. This supernate, $C$, and the residue, $R$, were counted in a welltype gamma counter.

Chromium release was calculated according to the expression:

$$
\%{ }^{51} \mathrm{Cr} \text { release }=\frac{\mathrm{C}(\mathrm{pm} \times 2 \times 10)}{\mathrm{C}(\mathrm{p}) \mathrm{m}+\mathrm{R}(\mathrm{pm})} .
$$

For each reaction the specific release was obtained by subtracting the release in the control tubes, which never exceeded $2 \%$. In some experiments, results were expressed as the number of target cells lysed per effector cell: Number of target cells lysed $=($ number of target cells $\times$ specific release $\div$ (number of effector cells $\times 100$ ) .

Phagocytosis. For determination of phagocytosis, the method of complement-mediated lysis described by Holm (1.3) was adopted. After incubation at $37^{\circ} \mathrm{C}$ under the same conditions as for cytotoxicity, the tubes were chilled in ice water; $1 \mathrm{mM}$ iodacetamide, which immediately blocks phagocytosis and lysis (13), was added. Nonphagocytosed erythrocytes were lysed by incubation at $37^{\circ} \mathrm{C}$ with a 10 -fold dilution of fresh human serum. After $30 \mathrm{~min}$ with frequent agitation the tubes were centrifuged and half of the supernate was withdrawn. This supernatant, $P$, and the residue, $R$, were counted in a gamma counter. Controls were included as for the cytotoxicity assay.

Phagocytosis was expressed as the percentage of target cells protected from complement-mediated lysis:

$$
\text { Phagocytosis }=\frac{(\mathrm{R} c \mathrm{pm}-\mathrm{P}(\mathrm{pm}) \times 100}{\mathrm{R} c \mathrm{pm}+\mathrm{P} \mathrm{cpm}} .
$$

Anaerobic conditions. Buffers were evacuated under zero pressure overnight in a vacuum chamber. An atmosphere of nitrogen was then introduced to the vacuum chamber and the bottles containing buffers were capped. Nitrogen that had percolated through a saturated dithionite solution was then bubbled through the buffers for $1 \mathrm{~h}$. 
Both target and effector cells were washed once in anaerobic medium. The anaerobic state was maintained by blowing nitrogen into the tubes when the caps were removed. Thereafter, the cells were put into a couveuse, $0.15 \mathrm{~m}^{3}$ vol, together with all the utensiles needed for the experiment. Nitrogen was then continuously blown into the couveuse and after $30 \mathrm{~min}$, when $25 \mathrm{~m}^{3} \mathrm{~N}$ had passed through the couveuse, the experiment was started.

The $\mathrm{O}_{2}$ concentration in the buffers was measured after ending the experiments. It was $6.3 \pm 2.3 \mu \mathrm{M}$ (mean $\pm \mathrm{SEM}$ for six experiments).

Degranulation. Assay mixtures were incubated as described for the cytotoxicity assay. At time indicated, $200 \mu \mathrm{l}$ of the supernate was withdrawn for the assay of lysozyme and lactate dehydrogenase (LDH). Total lysozyme and LDH were measured after ultrasonic disruption of unstimulated cells in $0.2 \%$ Triton X-100.

Lysozyme was measured turbidimetrically by the lysis of Micrococcus lysodeikticus (14). LDH was measured as described (15). Liberation was given as percentage of total amount of enzyme in unstimulated cells.

Hexose monophosphate shunt (HMPS). ${ }^{14} \mathrm{CO}_{2}$ liberation from $\left[1-{ }^{14} \mathrm{C}\right]$ - and $\left[6-{ }^{14} \mathrm{C}\right]$ glucose during the ADCC reaction was measured by incubating the cells in the presence of $1 \mathrm{mM}$ labeled glucose, sp act $2.2 \mathrm{mCi} / \mathrm{mmol}$. The reaction was terminated by injecting $100 \mu l 1 \mathrm{~N} \mathrm{NaOH}$ through the caps into the reaction mixture. After $1 \mathrm{~h}$ the content of the tubes was withdrawn and transferred to conical flasks in which $800 \mu \mathrm{l} 1 \mathrm{~N} \mathrm{HCl}$ had been placed. A rubber cap immediately sealed the flasks and the killed reaction mixture and the $1 \mathrm{~N}$ $\mathrm{HCl}$ were mixed to drive out the dissolved $\mathrm{CO}_{2}$. A center well of $1 \mathrm{~cm} \mathrm{Diam}$ contained $400 \mu \mathrm{l} 1 \mathrm{~N} \mathrm{NaOH}$ for the absorption of $\mathrm{CO}_{2}$. After standing overnight on a shaking bath, the content of the center well was withdrawn and counted in $10 \mathrm{ml}$ Instagel.

$\mathrm{O}_{2}$ consumption during phagocytosis of latex particles. $\mathrm{O}_{2}$ consumption was measured in a rapidly stirred thermostatized $37^{\circ} \mathrm{C}$ chamber with a Clark-type oxygen electrode built in under the stirrer (Rank Bros., Bottisham, England). The electrode was attached to a Beckman recorder (Beckman Instruments, Inc., Fullerton, Calif.). Addition of immunoglobulin G-coated latex particles (IgG-latex) $\left(10^{9}\right.$ particles $/ \mathrm{ml}$, final concentration) was made through a small whole in the stopper. Monocytes and neutrophils were used at a concentration of $3 \times 10^{6}$ cells $/ \mathrm{ml}$. Latex particles were coated with human IgG as described (16).

Superoxide production. PMA stimulation of superoxide production was measured as described (17) by following the increase in absorbance at $550 \mathrm{~nm}$ of a cell suspension containing $0.2 \mathrm{mM}$ cytochrome $c$.

Statistical analysis. Statistical significance was assessed using Wilcoxon's test for paired observations. A $P$ value $<0.05$ was considered significant.

\section{RESULTS}

ADCC and phagocytosis. Normal monocytes as well as normal neutrophils were effective in lysing immunoglobulin-coated erythrocytes, the neutrophils being slightly more effective than the monocytes (Fig. 1A and B).

Concomitant with their lysis, erythrocytes were phagocytozed. At the same time, the effector cells were stimulated to increase the activity of the HMPS and to degranulate, as seen from the increase in counts per minute of ${ }^{14} \mathrm{CO}_{2}$ recovered from $\left[1-{ }^{14} \mathrm{C}\right]$ glucose vs.
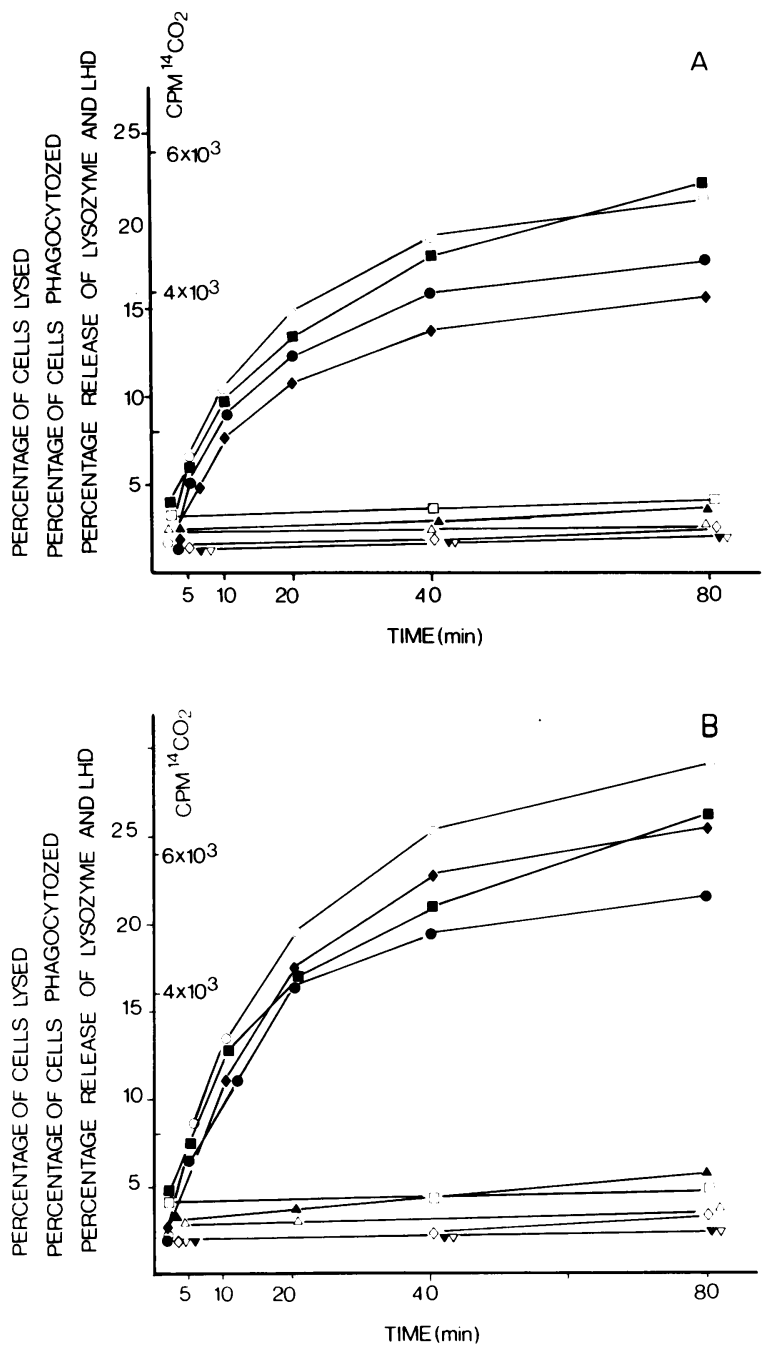

Figure 1 Time-course of cytolysis, phagocytosis, and postphagocytic events. In (A) the effector cells were monocytes and in (B) neutrophils. Effector/target cell ratio was $1: 1$ and the cell concentration was $10^{6}$ cells $/ \mathrm{ml}$. Cytolysis $(O)$, phagocytosis (O), counts per minute of ${ }^{1+} \mathrm{CO}_{2}$ from $\left[1-^{14} \mathrm{C}\right]$ glucose, stimulated cells $(\bullet)$, unstimulated cells (anti-B serum has been omitted) $(\diamond)$. Counts per minute of ${ }^{14} \mathrm{CO}_{2}$ from $\left[6-{ }^{14} \mathrm{C}\right]$ glucose, stimulated cells $(\boldsymbol{\nabla})$, unstimulated cells $(\nabla)$. Lysozyme liberation, stimulated cells $(\boldsymbol{\square})$, unstimulated cells ( $\square)$. Lactate dehydrogenase liberation, stimulated cells $(\boldsymbol{\Delta})$, unstimulated cells $(\triangle)$. Each figure given is the mean of six individual experiments. SEM: for cytolysis $\leq 0.8 \%$, for phagocytosis $\leq 1.2 \%$, for lysozyme $\leq 2.2 \%$, for $\mathrm{LDH} \leq 0.3 \%$, for ${ }^{14} \mathrm{CO}_{2}$ $\leq 250 \mathrm{cpm}$.

$\left[6-{ }^{14} \mathrm{C}\right]$ glucose and the specific liberation of lysozyme (lysozyme vs. LDH), respectively. The time-courses of lysis, HMPS activity, lysozyme liberation, and phagocytosis (Fig. 1A and B) showed that these phenomena are accurately correlated.

The number of target cells lysed per effector cell depends on the target/effector cell ratio; as seen in 
Fig. 2A and B, the increasing lysis by the effector cells was accompanied by increased phagocytosis, increased HMPS activity, and increased lysozyme liberation. Thus, it is apparent that ADCC in this system is correlated to phagocytosis and to the post phagocytic events (HMPS activation and degranulation).
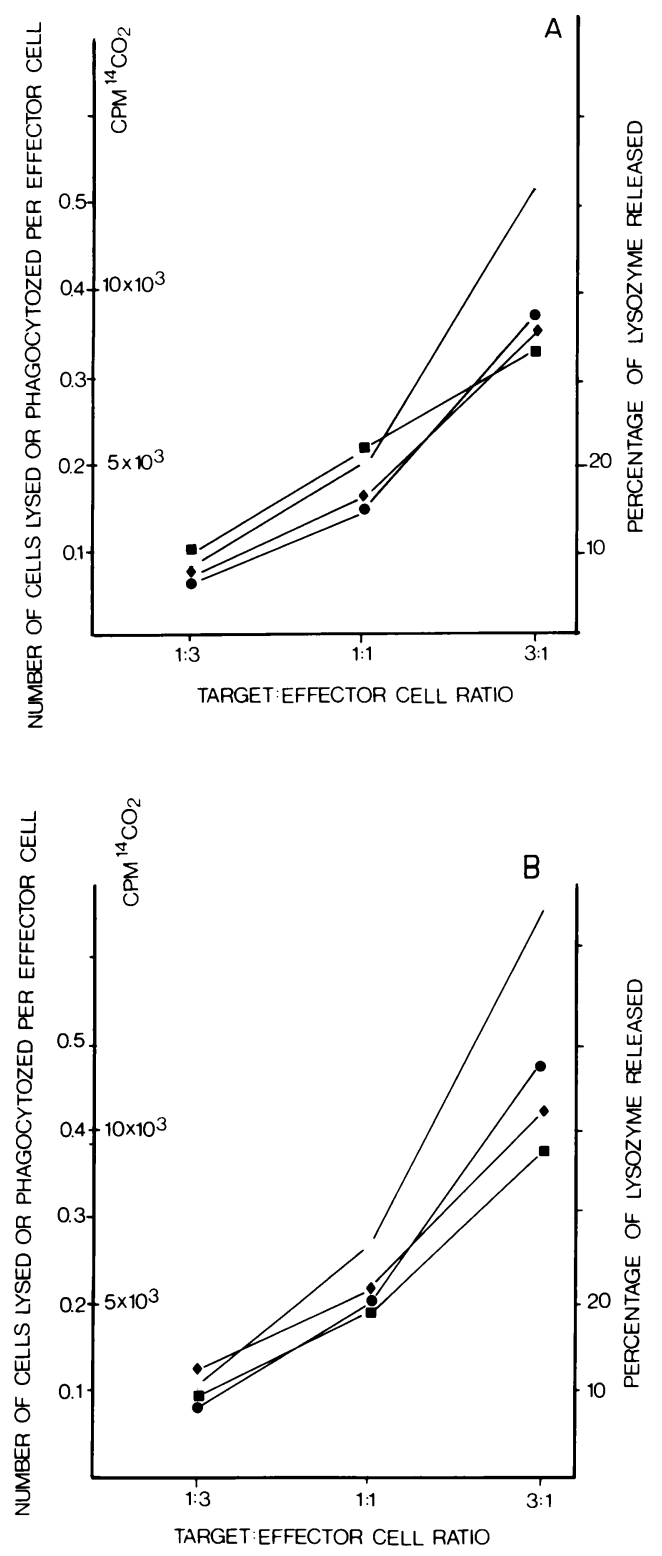

Figure 2 Effect of varying the effector/target cell ratio on cytolysis, phagocytosis, and postphagocytic events. In $\mathrm{A}$ the effector cells were monocytes and in B neutrophils. The time of incubation was $30 \mathrm{~min}$. The concentration of effector cells was $10^{6}$ cells $/ \mathrm{ml}$. Cytolysis $(\bigcirc)$, phagocytosis $(\bullet)$, counts per minute of ${ }^{14} \mathrm{CO}_{2}$ from $\left[1-{ }^{14} \mathrm{C}\right]$ glucose $(\bullet)$, lysozyme liberation (ם). Each figure is the mean of six individual experiments. SEM: for cytolysis $\leq 0.8 \%$, for phagocytosis $\leq 1.2 \%$, for lysozyme $\leq 2.3 \%$, for ${ }^{14} \mathrm{CO}_{2} \leq 200 \mathrm{cpm}$.
$A D C C$ and CGD. A study of the ADCC by monocytes and polymorphs from patients and carriers of CGD was carried out. $\mathrm{O}_{2}$ consumption of PMAstimulated neutrophils and superoxide production of PMA-stimulated monocytes and neutrophils were compared with ADCC (Table I). It is observed that monocytes and neutrophils share the defective response in postphagocytic metabolism as seen from $\mathrm{O}_{2}^{-}$production, that ADCC is severely depressed but not abolished in patients suffering from CGD, and that the degree of depression is correlated to the depression of oxygen consumption and superoxide production.

Degranulation and phagocytosis by effector cells from CGD patients and carriers were not depressed (data not given), showing that the defective ADCC by these cells is not secondary to defective target-cell effector-cell contact.

These findings indicate that the formation of reduced oxygen radicals, which normally takes place during phagocytosis by monocytes and neutrophils, is of importance for the ADCC by these cells.

This observation is substantiated by the finding that the ADCC by normal monocytes and neutrophils becomes almost as equally depressed under anaerobic conditions as the effector cells from CGD patients are under normal aerobic conditions (Table II). It was seen that, after readmission of oxygen, the cytotoxicity of monocytes and neutrophils returned to normal (cf. legend to Table II). The finding that phagocytosis and lysozyme liberation were unchanged under anaerobic conditions indicates that the anaerobic depression of ADCC is not caused by defective contact between target and effector cell or by a general depression of the energy metabolism of the effector cells. This is in agreement with the finding (Table III) that inhibitors of the oxydative phosphorylation, cyanide, azide, and 2,4-dinitrophenol, did not inhibit ADCC by any of the cell types investigated. The slight inhibition of monocyte-mediated ADCC by antimycin A was equally expressed under anaerobic as under aerobic conditions $(P>0.10)$ and thus was not the result of inhibition of mitochondrial oxydative phosphorylation. Neutrophils were not influenced by antimycin $A$.

To identify the oxygen radicals that are of significance for ADCC, the effect of scavengers of superoxide anion, hydroxyl radicals, and hydrogen peroxide, and the effect of inhibitors of catalase and myeloperoxidase were investigated (Table III).

No effect of catalase, cytochrome $c$, or superoxide dismutase was observed in any of the parameters investigated. As seen, azide, which in addition to blocking the mitochondrial oxydative phosphorylation also blocks the activity of catalase and myeloperoxidase and, thus, allows $\mathrm{H}_{2} \mathrm{O}_{2}$ to accumulate, stimulated the ADCC of both cell types investigated without affecting phagocytosis or lysozyme liberation. The data for 
TABLE I

Correlation between ADCC, Oxygen Consumption, and Superoxide Liberation

\begin{tabular}{|c|c|c|c|c|c|}
\hline & \multicolumn{2}{|c|}{ Neutrophils } & \multirow{2}{*}{$\frac{\text { Monocytes }}{\mathrm{O}_{2}^{-} \text {liberation }}$} & \multicolumn{2}{|c|}{$\mathrm{ADCC}$} \\
\hline & $\mathrm{O}_{2}$ consumption & $\mathrm{O}_{2}^{-}$liberation & & Monocytes & Neutrophils \\
\hline & \multicolumn{3}{|c|}{ fmol/min/cell } & \multicolumn{2}{|c|}{ \% Cr release } \\
\hline Normals & $4.15 \pm 0.12$ & $13.0 \pm 0.08$ & $2.5 \pm 0.16$ & $17.5 \pm 1.4$ & $22.5 \pm 1.8$ \\
\hline $\mathrm{CX}_{1}^{*}$ & 1.98 & 7.91 & 1.30 & 15.2 & 20.1 \\
\hline $\mathrm{CX}_{2}$ & 1.20 & 3.40 & 0.27 & 12.8 & 16.5 \\
\hline $\mathrm{CX}_{3}$ & 0.95 & 3.30 & 0.56 & 12.4 & 15.1 \\
\hline $\mathrm{CX}_{4}$ & 0.58 & 1.13 & 0.27 & 8.2 & 10.6 \\
\hline $\mathrm{CX}_{5}$ & 0.20 & 0.63 & 0.11 & 7.0 & 9.4 \\
\hline $\mathrm{X}+$ & () & 0 & 0 & 7.2 & 10.3 \\
\hline$A\}$ & 0 & 0 & 0 & 7.6 & 9.4 \\
\hline
\end{tabular}

$\mathrm{O}_{2}$ consumption of neutrophils $\left(3 \times 10^{6}\right.$ cells $\left./ \mathrm{ml}\right)$ stimulated with $5.0 \mu \mathrm{g} / \mathrm{ml}$ PMA (values from unstimulated cells have been subtracted). $\mathrm{O}_{2}^{-}$liberation of neutrophils ( $10^{6}$ cells $/ \mathrm{ml}$ ) and monocytes $\left(3 \times 10^{6}\right.$ cells $\left./ \mathrm{ml}\right)$ both stimulated with $5.0 \mu \mathrm{g} / \mathrm{ml}$ PMA, measured by the reduction of a 0.2-mM cytochrome $c$ solution. Cells were incubated for $30 \mathrm{~min}$ for the determination of cytotoxicity and phagocytosis. Figures for normals are mean $\pm S E M$ for eight individuals. Figures for the patients are mean of two closely agreeing measurements.

* $\mathrm{CX}_{(1)}$ indicates a carrier of CGD.

$\$ X$ is a boy suffering from the $X$-linked form of CGD.

$\$ A$ is a girl suffering from the autosomal recessive form of CGD.

lysozyme liberation are not shown. The stimulating effect of azide was neither observed on normal cells under anaerobic conditions nor on cells from CGD patients (data not shown). The hydroxyl radical scavenger, mannitol, considerably reduced the ADCC without affecting phagocytosis or lysozyme liberation. This effect of mannitol was not observed under anaerobic conditions, nor did mannitol reduce the ADCC by CGD patients (data not shown). This shows that the effects of mannitol in the concentration used is not a result of depression of the energy metabolism of the effector cells. It was ascertained that mannitol in the concentration used did not influence the rate of IgG-latex-induced oxygen consumption by normal monocytes or neutrophils (data not shown) and, thus, does not interfere with the generation of reduced oxygen radicals by these cells when undergoing phagocytosis.

Table IV shows that lysis of target cells is efficiently carried out by $0.025 \mathrm{U} / \mathrm{ml}$ xanthine oxidase. Omission of either xanthine or xanthine oxidase abolished the lysis. It is seen that the lysis is almost totally inhibited

TABLE II

Effect of Anaerobiosis on Cytotoxicity of Monocytes and Neutrophils

\begin{tabular}{lcr}
\hline & Monocytes & Neutrophils \\
\hline Aerobic conditions & & \\
$\quad$ Cytolysis, \% Cr liberated & $17.0 \pm 1.4$ & $22.5 \pm 1.8$ \\
Phagocytosis, \% cells phagocytozed & $14.1 \pm 2.2$ & $18.0 \pm 2.4$ \\
Lysozyme liberation, \% of total enzyme & $11.2 \pm 2.4$ & $15.1 \pm 2.1$ \\
Counts per minute of ${ }^{14} \mathrm{CO}_{2}$ from $\left[1{ }^{14} \mathrm{C}\right]$ glucose & $3.16 \times 10^{3} \pm 0.27$ & $5.1 \times 10^{3} \pm 0.43$ \\
Anerobic conditions & & \\
Cytolysis, \% Cr liberated & $9.2 \pm 1.7$ & $13.5 \pm 1.6$ \\
Phagocytosis, \% cells phagocytozed & $14.2 \pm 2.1$ & $17.3 \pm 2.5$ \\
Lysozyme liberation, \% of total enzyme & $11.8 \pm 2.1$ & $15.7 \pm 2.3$ \\
Counts per minute of ${ }^{14} \mathrm{CO}_{2}$ from $\left[1-{ }^{14} \mathrm{C}\right] \mathrm{glucose}$ & $0.7 \times 10^{3} \pm 0.16$ & $0.9 \times 10^{3} \pm 0.21$ \\
\hline
\end{tabular}

Incubations were for $30 \mathrm{~min}$. Effector and target cells were made anaerobic and used for both the aerobic and anaerobic experiments. For the aerobic experiment, cells were made aerobic by a buffer shift after standing under anaerobic conditions when the anaerobic experiment was carried out. Figures are mean \pm SEM for six individual experiments. 
TABLE III

Effect of Inhibitors and Scavengers of Oxygen Metabolism on Cytotoxicity and Phagocytosis

\begin{tabular}{|c|c|c|c|c|c|c|c|c|}
\hline \multirow[b]{3}{*}{ Additions } & \multicolumn{4}{|c|}{ Monocytes } & \multicolumn{4}{|c|}{ Neutrophils } \\
\hline & \multicolumn{2}{|c|}{ Aerobic } & \multicolumn{2}{|c|}{ Anaerobic } & \multicolumn{2}{|c|}{ Aerobic } & \multicolumn{2}{|c|}{ Anaerobic } \\
\hline & Cytolysis* & Phagocytosis* & Cytolysis* & Phagocytosis* & Cytolysis* & Phagocytosis* & Cytolysis* & Phagocytosis* \\
\hline None, control & 100 & 100 & 100 & 100 & 100 & 100 & 100 & 100 \\
\hline $\mathrm{SOD}, 50 \mu \mathrm{g} / \mathrm{ml}$ & $94 \pm 6.7$ & $100 \pm 3.8$ & NDt & ND & $90 \pm 5.9$ & $98 \pm 6.4$ & ND & ND \\
\hline Catalase, $4,000 \mathrm{U} / \mathrm{ml}$ & $95 \pm 2.4$ & $97 \pm 5.1$ & ND & ND & $105 \pm 2.6$ & $101 \pm 5.6$ & ND & ND \\
\hline Cytochrome $c, 0.2 \mathrm{m.M}$ & $92 \pm 1.9$ & $94 \pm 3.7$ & ND & ND & $102 \pm 2.0$ & $97 \pm 3.5$ & ND & ND \\
\hline Sodium azide, $1 \mathrm{~m} . \mathrm{M}$ & $144 \pm 5.8 \S$ & $102 \pm 6.2$ & $95 \pm 5.0$ & $102 \pm 6.6$ & $157 \pm 6.2 \S$ & $93 \pm 5.4$ & $93 \pm 5.1$ & $101 \pm 6.4$ \\
\hline Potassium cyanide, $1 \mathrm{mM}$ & $115 \pm 4.8$ & $98 \pm 4.9$ & ND & ND & $112 \pm 4.2$ & $98 \pm 3.9$ & ND & ND \\
\hline 2,4-Dinitrophenol, $10 \mu \mathrm{M}$ & $103 \pm 2.1$ & $105 \pm 2.9$ & ND & ND & $100 \pm 2.4$ & $99 \pm 5.2$ & ND & ND \\
\hline Antimycin A, $5 \mu . M$ & $78 \pm 3.9$ & $83 \pm 4.2$ & $82 \pm 6.1$ & $80 \pm 4.3$ & $96 \pm 4.8$ & $98 \pm 4.7$ & $104 \pm 3.5$ & $102 \pm 5.0$ \\
\hline Mannitol & $65 \pm 2.79$ & $95 \pm 4.0$ & $96 \pm 3.3$ & $99 \pm 5.2$ & $71 \pm 3.29$ & $92 \pm 4.1$ & $92 \pm 3.4$ & $93 \pm 3.9$ \\
\hline
\end{tabular}

Experiments were carried out under aerobic and anaerobic conditions. Six experiments were made for each condition. The time for incubation was $30 \mathrm{~min}$.

* Expressed as percentage of control (mean \pm SEM).

$\$$ ND, not done.

$\S P<0.001$ compared with control.

${ }^{4} P<0.05$ compared with control.

I $P<0.01$ compared with control.

by catalase and mannitol, and partly by superoxide dismutase. When superoxide dismutase and catalase, which had been heated to destroy enzymatic activity, were added, no inhibitory effect on cell lysis was observed. It was ascertained that $50 \mathrm{mM}$ mannitol did not

TABLE IV

Lyysis of IgG-sensitized Human Erythrocytes by a Xanthine-Xanthine Oxidase System

\begin{tabular}{lr}
\hline \multicolumn{1}{c}{ Supplements } & "Cr release \\
\hline & $\%$ \\
& \\
IgG-sensitized erythrocytes & $1.1 \pm 0.1$ \\
Xanthine oxidase & $1.3 \pm 0.1$ \\
+ IgG-sensitized erythrocytes & \\
Xanthine & $1.2 \pm 0.1$ \\
+ IgG-sensitized erythrocytes & \\
Xanthine oxidase + Xanthine & $26.7 \pm 0.8$ \\
+ IgG-sensitized erythrocytes & $1.3 \pm 0.1$ \\
+ catalase 1,500 U/ml & $9.8 \pm 0.2$ \\
+ superoxide dismutase 400 U/ml & $4.4 \pm 0.2$ \\
+ mannitol 50 mM & $24.3 \pm 1.2$ \\
+ boiled catalase & $25.3 \pm 0.9$ \\
+ boiled superoxide dismutase &
\end{tabular}

Incubations were as in ADCC experiments except that effector cells were replaced by $0.025 \mathrm{U} / \mathrm{ml}$ xanthine oxidase and $1 \mathrm{mM}$ xanthine, and that centrifugation of the reaction mixture before incubation was omitted. The time of incubation was $1 \mathrm{~h}$. Data are mean \pm SEM, of three experiments. Boiled catalase and boiled superoxide dismutase are enzymes that have been heated at $95^{\circ} \mathrm{C}$ for $5 \mathrm{~min}$ to destroy enzymatic activity. interfere with oxygen consumption of the xanthinexanthine oxidase system (data not shown).

A glucose-glucose oxidase system, $0.05 \mathrm{U} / \mathrm{ml}$, was not able to lyse target cells either at $\mathrm{pH} 5.8$ or 7.4 under the same conditions as used in the xanthine oxidase system (cf. legend to Table IV). Hydrogen peroxide, $5 \mu \mathrm{M}$ and $200 \mu \mathrm{M}$, either alone or in combination with $1 \mathrm{mM}$ azide likewise did not result in lysis of target cells when incubated for $1 \mathrm{~h}$.

\section{DISCUSSION}

The idea that oxygen radicals may be involved in ADCC by monocytes and neutrophils does not a priori seem remote. Both monocytes and neutrophils are known to reduce oxygen in a cyanide-insensitive way for the production of superoxide and hydrogen peroxide when the cells are stimulated to phagocytose $(18-21)$, and it is seen from our results that the process of ADCC, phagocytosis, and postphagocytic events are intimately correlated, although no causal relation may be deduced from these results.

From our observation that ADCC by human monocytes and neutrophils is $\sim 50 \%$ reduced when oxygen is removed, whereas phagocytosis and degranulation are unaffected by this treatment, it seems safe to conclude that oxygen plays a role for ADCC other than what might be secondary to oxydative phosphorylation in the mitochondria. In fact, our finding that phagocytosis and degranulation are unaffected by anaerobiosis and by the lack of effect of cyanide and dinitrophenol on ADCC, rules out any significant demand of energy 
provided by oxydative phosphorylation for the ADCC and phagocytosis by both monocytes and neutrophils. This is confirmed by the finding that oxydation of carbon in position six of glucose to $\mathrm{CO}_{2}$ is not enhanced during ADCC, which shows that the activity of the citric acid cycle is not increased during ADCC. The observation that ADCC by both monocytes and neutrophils from patients with CGD is halved compared with cells from normals gives further support to the idea that oxygen radicals play an essential role in ADCC. This observation has also been made by Clark and Klebanoff (7) investigating neutrophils and by Katz et al. (8) investigating both monocytes and neutrophils from CGD patients, although the degree of depression observed in CGD patients in these studies was somewhat higher than those observed by us. The results are, however, contradictory to those of Fleer et al. (10), who found that ADCC was totally dependent on the release of lysosomal enzymes. The basis for this divergence remains obscure.

Further support for the idea of reduced oxygen species being of significance in ADCC is gained by the observation that mannitol inhibits ADCC in concentrations that do not affect phagocytosis or degranulation during the ADCC reaction. The finding that mannitol is without effect on ADCC by cells from CGD patients and during anaerobic incubation of cells from normals strongly implies that the effect of mannitol is a result of its action as a hydroxyl radical scavenger (22). It has been observed that hydroxyl radicals are formed by stimulated monocytes and neutrophils $(23,24)$. In recent studies by Green et al. (25) and Rosen and Klebanoff (26) using the technique of electron spin resonance spectroscopy, evidence for significant generation of hydroxyl radicals by phagocytosing neutrophils was found. It was seen that azide stimulated the formation of hydroxyl radicals and that the production of hydroxyl radicals was higher by cells deficient in myeloperoxidase than by normal cells. This corresponds well with our observation that azide stimulates ADCC and with the observation of Clark and Klebanoff (7) that ADCC by myeloperoxidase-deficient neutrophils is enhanced. SOD, which dramatically reduces the ESR response of hydroxyl radicals $(25,26)$, did not influence ADCC in our system. This has also been observed by Clark and Klebanoff. Recently, Capsoni et al. (27) have reported some depression of SOD on ADCC by neutrophils, although the level reached was far higher than ADCC by neutrophils from CGD patients. The lack of effect of SOD on ADCC does not rule out the possibility that hydroxyl radicals actively participate in ADCC because ADCC is dependent on intimate membrane contact between effector cell and target cell (4); it is highly likely that SOD, cytochrome $c$, and catalase do not gain access to the site of formation and action of hydroxyl radicals.
The involvement of hydroxyl radicals in target cell lysis gains further support from the observation that target cells are effectively lysed by xanthine-xanthine oxidase. This shows that lysis can be obtained by the radicals produced in this system $\left(\mathrm{O}_{2}^{-}, \mathrm{H}_{2} \mathrm{O}_{2}\right.$, and $\mathrm{OH}$, 28) and, thus, that lysosomal enzymes delivered by effector cells are not a necessary prerequisite for lysis of erythrocytes. The observation that the lysis of target cells by xanthine oxidase is abolished by catalase rules out that $\mathrm{O}_{2}^{-}$is the direct effector molecule. On the other hand, the strong depression of lysis observed by superoxide dismutase, which accelerates the formation of $\mathrm{H}_{2} \mathrm{O}_{2}$, shows that lysis is not caused by $\mathrm{H}_{2} \mathrm{O}_{2}$ directly. This is also in accordance with the lack of lysing effect of glucose oxidase and $\mathrm{H}_{2} \mathrm{O}_{2}$. These observations together with the strong inhibitory effect of mannitol indicates that it is the hydroxyl radicals generated by xanthine-xanthine oxidase that are effector molecules.

\section{ACKNOWLEDGMENTS}

The authors wish to thank Dr. Christian Koch, Rigshospitalet, Copenhagen and Dr. Kirsten Staehr Johansen, Statens Serum Institut, Copenhagen for allowing us to study CGD patients originally diagnosed by them. The excellent technical assistance of Mrs. Jonna Guldberg, Miss Anni Jespersen, and Miss Birgit Krarup is gratefully acknowledged.

This work was supported by the Danish Medical Research Council grants 512-15485 and 512-20089 and by grants from Fonden til Laegevidenskabens Fremme and Novos Fond.

\section{REFERENCES}

1. Holm, G. 1972. Lysis of antibody-treated human erythrocytes by human leukocytes and macrophages in tissue culture. Int. Arch. Allergy Appl. Immunol. 43: 671-682.

2. MacDonald, H. R., G. D. Bonnard, B. Sordat, and S. A. Zawodnik. 1975. Antibody-dependent cell-mediated cytotoxicity: heterogeneity of effector cells in human peripheral blood. Scand. J. Immunol. 4: 487-497.

3. Levy, P. C., G. M. Shaw, and A. F. LoBuglio. 1979. Human monocyte, lymphocyte and granulocyte antibodydependent cell-mediated cytotoxicity toward tumor cells. I. General characteristics of cytolysis. J. Immunol. 123: 594-599.

4. Fleer, A., M. L. J. van Schaik, A. E. G. Kr. van dem Borne, and C. P. Engelfriet. 1978. Destruction of sensitized erythrocytes by human monocytes in vitro. Effects of cytochalasin B, hydrocortisone and colchicine. Scand. J. Immunol. 8: 515-524.

5. Penfold, P. L., A. H. Greenberg, and I. M. Roitt. 1976. Characteristics of the effector cells mediating cytotoxicity against antibody-coated target cells. III. Ultrastructural studies. Clin. Exp. Immunol. 23: 91-97.

6. LoBuglio, A. F., R. S. Cotran, and J. H. Jandl. 1967. Red cells coated with immunoglobulin G: binding and sphering by mononuclear cells in man. Science (Wash. D. C.). 158: $1582-1585$.

7. Clark, R. A., and S. J. Klebanoff. 1977. Studies on the mechanism of antibody-dependent polymorphonuclear leukocyte-mediated cytotoxicity. J. Immunol. 119: 14131418. 
8. Katz, P., C. B. Simone, P. A. Henkart, and A. S. Fauci. 1980. Mechanisms of antibody-dependent cellular cytotoxicity. J. Clin. Invest. 65: 55-63.

9. Holmes, B., A. R. Page, and R. A. Good. 1967. Studies on the metabolic activity of leukocytes from patients with a genetic abnormality of phagocytic function. J. Clin. Invest. 46: 1422-1432.

10. Fleer, A., D. Roos, A. E. G. Kr. van dem Borne, and C. P. Engelfriet. 1979. Cytotoxic activity of human monocytes towards sensitized red cells is not dependent on the generation of reactive oxygen species. Blood. 54: 407411.

11. Boyum, A. 1968. Separation of leukocytes from blood and bone marrow. Scand. J. Clin. Lab. Invest. 21 (Suppl.): 77-89.

12. Leder, L-D. 1967. Der Blut Monocyt. Springer-Verlag, Berlin. 226.

13. Holm, G. 1974. Mechanisms of antibody-induced hemolytic activity of human blood monocytes. In Activation of Macrophages. W. H. Wagner and H. Holm, editors. Elsevier North-Holland, Inc., Excerpta Medica Inc., Amsterdam. 63-70.

14. Klass, H. J., J. Hopkins, G. Neale, and T. J. Peters. 1977. The estimation of serum lysozyme: a comparison of four assay methods. Biochem. Med. 18: 52-57.

15. Bergmeyer, H. V. 1974. Methods of Enzymatic Analysis. Verlag Chemie GmbH, Weinheim, West Germany. Academic Press, Inc., New York. 574-579.

16. Segal, A. W., and O. T. G. Jones. 1979. The subcellular distribution and some properties of the cytochrome $b$ component of the microbicidal oxidase system of human neutrophils. Biochem. J. 182: 181-188.

17. Borregaard, N., K. S. Johansen, and V. Esmann. 1979. Quantitation of superoxide production from normals and 3 types of chronic granulomatous disease. Biochem. Biophys. Res. Commun. 90: 214-219.

18. Sbarra, A. J., and M. L. Karnovsky. 1959. The biochemical basis of phagocytosis. J. Biol. Chem. 234: 1355-1362.
19. Johnston, R. B., Jr., B. B. Keele, M. P. Misra, J. E. Lehmeyer, L. S. Webb, R. L. Baehner, and K. K. Rajagopalan. 1975. The role of superoxide anion generation in phagocytic bactericidal activity. J. Clin. Invest. 55: 1357-1372.

20. Johnston, R. B., Jr., J. E. Lehmeyer, and L. A. Guthrie. 1976. Generation of superoxide and chemiluminescence by human monocytes during phagocytosis and in contact with surface-bound immunoglobulin G.J. Exp. Med. 143: $1551-1556$.

21. Sagone, A. L., Jr., G. W. King, and E. M. Metz. 1976. A comparison of the metabolic response to phagocytosis in human granulocytes and monocytes. J. Clin. Invest. 57: $1352-1358$

22. Halliwell, B. 1978. Superoxide-dependent formation of hydroxyl radicals in the presence of iron salts. FEBS (Fed. Eur. Biochem. Soc.) Lett. 96: 238-242.

23. Weiss, S. J., G. W. King, and A. F. LoBuglio. 1977. Evidence for hydroxyl radical generation by human monocytes. J. Clin. Invest. 60: 370-373.

24. Tauber, A. I., and B. M. Babior. 1977. Evidence for hydroxyl radical production by human neutrophils. $J$. Clin. Invest. 60: 374-379.

25. Green, M. J., H. A. O. Hill, M. J. Okolow-Zubkowska, and A. W. Segal. 1979. The production of hydroxyl and superoxide radicals by stimulated human neutrophilsmeasurements by EPR spectroscopy. FEBS (Fed. Eur. Biochem. Soc.) Lett. 100: 23-26.

26. Rosen, H., and S. J. Klebanoff. 1979. Hydroxyl radical generation by polymorphonuclear leukocytes measured by electron spin resonance spectroscopy. J. Clin. Invest. 64: $1725-1729$.

27. Capsoni, F., P. L. Meroni, G. F. Ciboddo, and G. Colombo. 1979. Cytotoxic mechanism in white blood cells. N. Engl. J. Med. 300: 44. (Abstr.)

28. Beauchamp, C., and I. Fridovich. 1970. A mechanism for production of ethylene from methional. The generation of the hydroxyl radical by xanthine oxidase. J. Biol. Chem. 245: 4641-4646. 